\title{
NAZEWNICZE POWROTY W KONTEKŚCIE JEZZYKOWYCH UNIWERSALIÓW. DAWNE I WSPÓŁCZESNE NAZWY MIEJSCOWE O CHARAKTERZE INTERNACJONALNYM
}

Słowa tematyczne: nazwy intertekstualne, transonimizacja, egzonimy, nazwy miejscowe, nazwy apartamentowców

System onimiczny bazuje tak na leksyce apelatywnej, jak i na innych nazwach własnych. W wyniku tworzenia nowych propriów (obu wspomnianych grup motywacyjnych) uruchamiane są strategie słowotwórcze lub semantyczne, a także zwykłe przeniesienia rzeczowników pospolitych bądź własnych. Odapelatywne jednostki prymarnie charakteryzują referenta (bezpośrednio lub niebezpośrednio, tj. metaforycznie), wobec czego po zerwaniu związku referencyjnego użytkownik nazwy wplata je w uzależnione od doświadczenia i wiedzy relacje nazwa - referent. Nie mniej zróżnicowane ścieżki konotacyjne powstają w odniesieniu do nazw deproprialnych, tworzonych w wyniku tzw. transonimizacji. Tę niejednorodność ilustrują próby ich ujmowania w kategoriach onimów przeniesionych (Bubak, 1965, 1966), ponowionych (Treder, 1979, 1980), relacyjnych (Borek, 1988), podziałowych (Zierhofferowa, 1988), wtórnych (Kopertowska, 1993), narracyjnych i intertekstualnych (Rutkiewicz-Hanczewska, 2008, s. 418-423; 2013, s. 129). Każdy z przywołanych terminów ujawnia poszczególne funkcje tak tworzonych nazw, od formalnych, polegających na kolejnym, wtórnym użyciu nazwy w odniesieniu do nowego obiektu, $\mathrm{z}$ którym ten pierwszy jest $\mathrm{w}$ jakiejś relacji, po funkcję takich działań, jaką jest zapewne kontynuowanie biografii danych przestrzeni i nawiązywanie z nimi dialogu, zapośredniczenie dwu nominowanych wspólnym mianem przestrzeni.

Pośród takich nazw istnieje jedna wyjątkowa grupa jednostek nawiązujących do innych propriów, wśród których znajdują się powszechnie znane jednostki, tj. utrwalone kulturowo, tzw. egzonimy. One w zasadzie nie tyle ukrywają nić motywującą powstanie nowej jednostki onimicznej, co w bezpośredni sposób przywołują zbiór skojarzeń, wartość znaczeniową, konotacyjną pierwowzoru, zwanego inaczej architekstem. Ta bezpośredniość w przypadku translokacji oni- 
mu z jednej przestrzeni kreacyjnej do drugiej jest tym wyrazistsza, im bardziej znany pierwowzór.

Z punktu widzenia współczesnych twórców nazw handlowych ten właśnie sposób pomnażania onomastykonu należy do technik najbardziej nośnych perswazyjnie i pozbawionych ryzyka nieodkodowania zamysłu kreatora. Wybór gotowego tekstu bez dodatkowych wyróżników morfologicznych wiąże się z łatwością rekonstrukcji onimu. Wiadomo bowiem, że struktura takich nazw (powstających w świadomym akcie kreacji) zwykle tworzona jest z myślą o ożywieniu określonych skojarzeń, a ich przywołanie staje się możliwe po wcześniejszym odtworzeniu potencjalnego dawcy. Nie mają tej formy totalnej czytelności nazwy powstałe drogą morfologicznych przekształceń.

Transonimizacja należy do bardzo nośnych sposobów kreowania nowych toponimów również $\mathrm{w}$ przypadku nazw powstających $\mathrm{w}$ warunkach naturalnych (tj. w nieświadomym akcie kreacji). Chociaż tu kreatorowi nie zależy na jakimkolwiek odkodowywaniu procesu ich tworzenia, to sam pomysł nazywania obiektów funkcjonującymi w innych przestrzeniach określeniami należy do popularnych. Oznaczenie obiektu istniejącą wcześniej nazwą równa się przypisaniu mu zbliżonych cech, jakie ewokuje w umyśle kreatora użyte sekundarnie proprium lub pokazuje, w jakiej relacji znajdują się referenci architekstu (hipotekstu) i hipertekstu (pewien rodzaj przyległości).

Transonimizacja, zwana też transtekstualizacją (Rutkiewicz-Hanczewska, 2013, s. 137), pozwala na odświeżanie zasobów nazewniczych danego systemu. Ponieważ jeden znak onimiczny można wielokrotnie wykorzystywać w różnych funkcjach, rodzi się możliwość nawiązywania dyskursu między poszczególnymi przestrzeniami proprialnymi, który jak pokazuje współczesna toponimia może być ciągle odtwarzany. Stanowi on bowiem ilustrację sposobu myślenia i odczuwania nominowanej rzeczywistości przez obecnie żyjących. Celem artykułu jest omówienie historii i specyfiki tworzenia takich właśnie onimów w funkcji określania nazw miejscowych, jakie powstawały w przeszłości oraz jakie tworzy się współcześnie, a dokładnie chodzi tu o nazwy internacjonalne, tj. egzonimy, jednostki nazywające obiekty położone poza granicami danej przestrzeni terytorialnej (np. Polski), gdzie obowiązuje odmienny system nazewniczy. Z uwagi na ich niezmienną popularność można mniemać, że stanowią wyraz powtarzalnych, stałych sposobów pomnażania areału onimicznego zgodnie ze stałymi potrzebami ich twórców, zarówno tych nieświadomie kreujących nowe nazwy dla nowych wsi i ich części, jak i twórców z wyboru, świadomie stwarzających nowe byty językowe dla nowych form osiedlania się współczesnych.

Dziś też powstają nowe osady, lecz nie mają charakteru typowych, znanych z czasów średniowiecznej lokacji wsi. Obecnie w tej funkcji występują osiedla mieszkaniowe oraz współtworzące je grupy apartamentowców. Ich nazwy mogą 
pełnić funkcję nazw miejscowych. W niektórych klasyfikacjach proprialnych nazwy osiedli mieszkaniowych uznaje się za urbanonimy (Šrámek, 2010, s. 39; Myszka, 2016, s. 43), z kolei określenia apartamentowców traktowane są jako chrematonimy, do których zalicza się nazwy budynków (Breza, 1988, s. 122). W szerokiej ${ }^{1}$ definicji nazwy miejscowej jej zakresem obejmuje się wszelkie zamieszkane miejsca: miasta, wsie, części miast i wsi, osiedla mieszkaniowe², place, aleje i ulice (Kopertowska, 1984, s. 12). Nieco węższe znaczenie znajdujemy w „Encyklopedii językoznawstwa ogólnego” (Polański, 1995, s. 354), gdzie za nazwę miejscową uznaje się określenie osiedla ludzkiego, miasta, wsi i przysiółka, a także dzielnicy. Podobną definicję przyjmuje Z. Zagórski ${ }^{3}$ (2008, s. 31). U schyłku XX w. również nazwy wolno stojących zabudowań, budynków wiejskich, postulowano włączać do kategorii nazw osiedli (Pawłowski, 1965, s. 5) lub szerzej nazw placów, przysiółków i większych osiedli (Pospiszylowa, 1984, s. 92).

Biorąc pod uwagę przytoczone wyżej szerokie definicje nazwy miejscowej, także określenia apartamentowców - po uwzględnieniu przemian społecznogospodarczo-przestrzennych miast - można uważać za współczesne odpowiedniki nazw miejscowych. Są bowiem miejscem zamieszkania większej grupy ludzi, stanowią współczesny rodzaj skupiska ludzkiego. Wobec powyższego w przeszłości osadami były wsie, obecnie są nimi osiedla i najnowsze apartamentowce, nazywane nowocześnie, dla podniesienia ich prestiżu, rzeczownikami w rodzaju: atelier (Bukowe Atelier w Wiśle), atrium (Atrium Park w Bydgoszczy), casa (Casa Azul w Józefowie), dwór (Dwór Marcelin w Poznaniu), house (Pola Negri House w Sosnowcu), park (Królewski Park w Warszawie), port (Port Żerań w Warszawie), prestige (Apartamenty Prestige w Wieliczce), residence (Rożnowska Residence w Warszawie), rezydencja (Rezydencja Wspól$n a$ w Warszawie), tower (Odra Tower we Wrocławiu), villa, willa (Villa Galicja w Krakowie, Willa nad Potokiem w Katowicach).

\section{DAWNE PRZENIESIONE NAZWY MIEJSCOWE}

Przenoszenie zagranicznych nazw miejscowości na osady zakładane w Polsce może odbywać się pod warunkiem ich upowszechnienia się, a wiedza o nich

1 Węższa definicja nazwy miejscowej swoim zakresem obejmuje nazwy tylko miast, wsi lub przysiółków (S. Urbańczyk, 1991, s. 216; M. Rutkiewicz, 2002, s. 8).

2 W ujęciu K. Handke (1989, s. 8-9) nazwy dzielnic, osiedli, przedmieść, kwartałów itp. nazywa się tzw. obszarami, które stanowią jedną z trzech podgrup onimów tworzących nazewnictwo miejskie.

3 Zdaniem Z. Zagórskiego (2008, s. 31) „nazwy części miasta (dzielnic łącznie ze śródmieściem, osiedli itp.) traktuje się w związku ze stanem współczesnym, charakterem i funkcją oraz przeszłością (pochodzeniem) tych obiektów, do których te nazwy się odnoszą, jako - w ogólnym ujęciu — nazwy miejscowe (tzn. tak jak nazwy poszczególnych miejscowości)”. 
i ich denotatach należała pierwotnie do osób odbywających dalekie podróże, wśród których byli wówczas kupcy oraz duchowni piastujący wysokie stanowiska państwowe. W połowie XIII stulecia rozpoczęło się upowszechnianie szkolnictwa, które później pozwalało zdobywać wiedzę wyższego stopnia w szkołach klasztornych i na zagranicznych uniwersytetach. Część osób podejmowała swoje podróże $\mathrm{w}$ związku $\mathrm{z}$ istotnymi misjami dyplomatycznymi czy pielgrzymkami (Wolnicz-Pawłowska, 2007, s. 149-150; Zierhofferowie, 2007, s. 90-91). Zacieśnienie kontaktów ze wspólnotą zachodnioeuropejską, zwrócenie się w stronę papiestwa i cesarstwa ,stwarzało wśród ówczesnej elity kulturalnej potrzebę zaznajomienia się $\mathrm{w}$ procesie edukacji z opisem znajdujących się tam krajów i zmuszało do poznawania ich nazewnictwa geograficznego" (Zierhofferowie, 2007, s. 90-91), które później można było przywoływać do oznaczania swojej przestrzeni.

$\mathrm{O}$ pierwszych nazwach przeniesionych o charakterze internacjonalnym w funkcji nazw osad wspominają nieliczne i skąpe źródła średniowieczne. Trudne też jest dociekanie motywacji takich nazw. Z pewnością nazywający musieli znać pierwotną osadę, której nazwę zdecydowali się przenieść. Dla przykładu dzisiejszy Kobylin z okolic Leszna w XIII wieku okresowo nazywano Nowa Wenecja (Rospond, 1984, s. 148; NMPol V 19). Jak pokazują późniejsze tego typu nominacje, istotne mogło być tu podobieństwo referentów lub włoskie pochodzenie mieszkańców. $Z$ drugiej połowy XIV wieku mamy też poświadczenia dla nazwy miejscowej Rzym w województwie kujawsko-pomorskim (de Roma 1390, de Rzym 1415, NMPol XI 166). Fundujący ją urbonim w porównaniu z innymi egzonimami pojawia się w polszczyźnie najwcześniej i zdaniem Karola i Zofii Zierhofferów $(2007$, s. 15, 20) należy do dziedzictwa wspólnoty prasłowiańskiej. Słowianie przejęli go bez pośrednictwa innych języków (*Rimъ). Pojawia się on już w „Kazaniach gnieźnieńskich” czy w „Legendzie o świętym Aleksym".

Wobec powyższego o przenoszeniu pierwszych nazw obszarów zagranicznych do rodzimego systemu nazewniczego można już mówić w średniowieczu. Podróżujący ówcześnie Polacy musieli orientować się w geografii ówczesnej Europy, a nawet świata. Według K. i Z. Zierhofferów (2007, s. 103, 202) znacząca liczba łacińskich nazw miejscowości europejskich zawartych w starożytnych kronikach i źródłach średniowiecznych ma swoje poświadczenia $\mathrm{w}$ formie zaadaptowanej przez polszczyznę „, zasadzie w piśmiennictwie szesnastowiecznym", co nie oznacza, że nie było ich w użyciu w wiekach wcześniejszych. Charakteryzowany model nazewniczy jest znany już wówczas także poza granicami kraju. Wraz z odkrywaniem nowych lądów na świecie pojawiają się nazwy w rodzaju: Nowa Funlandia (odkryta w 1497 r.; prowincja Kanady), Nowa Anglia (odkryta w 1620 r.; północno-wschodni region USA) 
czy Nowa Kaledonia (odkryta w 1774 r.; por. Caledonia — łac. nazwa Szkocji; terytorium zamorskie zależne od Francji). To właśnie w epoce kolonialnej, którą zapoczątkował Krzysztof Kolumb, doszło do rozprzestrzenienia się nazewnictwa geograficznego Europy na innych kontynentach świata (Czerny, 2011, s. 89).

Mówimy zatem o popularnym, a nawet uniwersalnym sposobie nominowania obiektów geograficznych (zob. tabelę $\mathrm{nr}$ 1). Ten uniwersalizm wyraża się za pomocą mechanizmu metafory, pozwalającej na daleko idące uogólnianie, porównywanie dwu, w naszym przypadku, różnych terytorialnie obiektów (obcych i rodzimych), które z jednej strony łączy wygląd, funkcja, ranga, położenie lub pochodzenie mieszkańców. To nominacja ${ }^{4}$ koncentryczna, przenosząca nazwy (egzonimy) do rodzimego systemu nazewniczego („obce do swojego”). $\mathrm{Z}$ drugiej strony, można mówić o nominacji ekscentrycznej, w wyniku której powstają nazwy przenoszone do obcego systemu nazewniczego (,,swoje do obcego"), bo kolonializowanego, anektowanego. Tu przeniesiona nazwa, którą raczej można określać nazwą przyniesioną, ma charakter stricte pamiątkowy, nostalgiczny ${ }^{5}$, wynika bądź z tęsknoty za krajem ojczystym (Wolnicz-Pawłowska, 2007, s. 151-152), bądź jest symbolem podboju i ucisku kolonialnego, wyrażającym europejską dominację (Czerny, 2011, s. 89-90).

Drugim źródłem nazw przeniesionych (o charakterze koncentrycznym) są określenia krain o rodowodzie biblijnym, które w funkcji nazw przeniesionych zaczęły pojawiać się w XVII wieku'. Z uwagi na znaczenie kultury chrześcijańskiej i upowszechnianie się tekstów biblijnych należały one do popularnych egzonimów. Łatwo je było ponawiać. Ich funkcja pierwotnie polegała nie tylko na powielaniu określonego onimu, lecz także na upodabnianiu nowej osady do swojego nazewniczego pierwowzoru. Najdobitniej to widać na przykładzie najpopularniejszego architekstu, jakim była Kalwaria, nazwa wzgórza w Jerozolimie, znanego z egzekucji skazańców, w tym Jezusa. Osady tak nazywane

4 Pamiętać należy również o przenoszeniu nazw w obrębie jednego, rodzimego systemu nazewniczego (,swoje do swojego”). Dla przykładu w Polsce znaleźć można nazwy odwołujące się do innych lokalnych określeń typu Karpaty w funkcji nazwy pól, a także nazwy tzw. dyferencyjne typu: Boruja Nowa, Boruja Stara, Boruja Kościelna (od nazwy wsi Boruja) czy Nowy Tomyśl i Stary Tomyśl (pierwotnie Tomyśl) czy ponowione (Treder, 1979, s. 22) w rodzaju Bobrówka (nazwa rzeki), Bobrówka (nazwa lasu) (zob. Wolnicz-Pawłowska, 2007, s. 151).

5 Dla przykładu wyspy na wodach indonezyjskich (okolice Jawy, dzisiejszej Dżakarty), odkryte na początku XVII stulecia przez Holendrów, nazywano imionami miast, nazwami statków, nazwiskami ich oficerów. Jeden z takich „nostalgicznych” archipelagów, składający się z kilku wysepek, określano nazwami miast holenderskich (Ormeling, 2009, s. 785-786, fig. 5).

6 Z drugiej połowy XV wieku pochodzi dzisiejsza wieś Jeruzal w gminie Kowiesy. Ponieważ to osada młyńska, u podstawy jej nazwy znajduje się zapewne imię młynarza, niejakiego Jerusela. Dopiero ono pochodzi od nazwy miejscowej Jeruzalem (zob. inaczej NMPol IV 174). Nazwy młynów bardzo często miały motywacje dzierżawczą. 
zakładano w XVII-XVIII wieku, np. Góra Kalwaria, Kalwaria Zebrzydowska, Kalwaria Pacławska. Zdarzało się, że w ten sposób nazywano istniejące już wsie, na terenie których budowano kalwarie, czyli zespoły kościołów i kaplic symbolizujących etapy Męki Pańskiej (Bilska, 1995, s. 200-202, 205). Stanowiły one prawdziwe imago mundi, wyobrażenie przestrzeni świętej.

Przeniesieniu nazwy Kalwaria towarzyszyło dość wierne budowanie, odtwarzanie nowej Jerozolimy, z zachowaniem odpowiednich odległości między miejscami związanymi z Męką Pańską (por. Kalwaria Zebrzydowska, Kalwaria Pactawska), bądź w miarę wierne przenoszenie jedynie tematyki poszczególnych kaplic (Góra Kalwaria i kalwaria w Wambierzycach).

Sięgnięcie po wspomniany architekst, a następnie upodabnianie osad kalwaryjnych do krajobrazu jerozolimskiego przyczyniło się do przenoszenia także innych nazw o proweniencji biblijnej na obiekty lokowane w pobliżu wspomnianych osad, a później także na inne wsie lub przysiółki. Wśród nich najczęściej pojawiały się: Jerozolima, Betlejem oraz Palestyna (Rutkiewicz-Hanczewska, 2007, s. 431-441). Dla przykładu kalwarię w Wejherowie nazwano Jerozolima Kaszubska, a w Glotowie Warmińska Jerozolima. Znane są też przeniesienia egzonimów w rodzaju: Cedron (nazwa części wsi Brody w gminie Kalwaria Zebrzydowska), Cedroński Młyn (osada młyńska w Wejherowie) (Rospond, 1985, s. 159; Treder, 1980, s. 56-57), Emaus (Emaus Stary i Nowy - części Gdańska Siedlce), Jerycho (przysiółek w okolicy Bydgoszczy), Góra Tabor (Tabor - nieistniejąca wieś warszawska), Góra Oliwna (Oliwa - część gdańska), Józefata Dolina (nazwa przysiółka koło Kartuz) czy Galilea (nazwa części Rytla).

Wspomnieć trzeba, że tego typu przeniesienia najliczniej występują na Pomorzu, Kaszubach, Mazurach, Mazowszu oraz w Małopolsce, co - zdaniem J. Tredera (1980, s. 57) - wiąże się z charakterystycznym ukształtowaniem terenu, zbliżonym do krajobrazu jerozolimskiego, oraz z protestanckim zwyczajem określania osiedli mieszkaniowych nazwami o biblijnej proweniencji.

Najdawniejsze przeniesienia nazw biblijnych nie wiążą się jedynie $\mathrm{z}$ upodabnianiem nazywanych obiektów do pierwotnego referenta. Czasem nazywano tak miejsca zamieszkane przez osoby przynależące do społeczności żydowskiej, ich swoiste enklawy. Historyczne nazwy tego rodzaju tworzono przez dodanie do architekstu dodatkowego członu, podkreślającego powtórność nominacji. Dla przykładu w 1774 roku pod Warszawą (na terenie między rogatkami Warszawy, zwanymi później Jerozolimskimi, i granicą wsi Wielka Wola) założono osadę o nazwie Nowa Jerozolima dla ludności żydowskiej. Jej założyciel, A. Sułkowski, chciał w ten sposób zapewne upamiętnić nazwę pierwotnej stolicy tej grupy etniczno-religijnej (Handke, 1998, s. 146). 
Tabela 1. Rodzaje dawnych intertekstów występujących najczęściej w funkcji nazw miejscowości i ich części

\begin{tabular}{|c|c|c|c|c|c|}
\hline $\begin{array}{l}\text { Nazwy } \\
\text { państw }\end{array}$ & Nazwy miast & $\begin{array}{l}\text { Nazwy } \\
\text { kontynen- } \\
\text { tów }\end{array}$ & $\begin{array}{l}\text { Nazwy wysp, } \\
\text { krain geogra- } \\
\text { ficznych, gór }\end{array}$ & $\begin{array}{l}\text { Nazwy biblijnych } \\
\text { krain, rzek }\end{array}$ & $\begin{array}{l}\text { Nazwa mi- } \\
\text { tologicznej } \\
\text { krainy }\end{array}$ \\
\hline Abisynia (9)* & Akwizgran (1) & Ameryka (23) & Azory (2) & Babilon (3) & Arkadia (1) \\
\hline \begin{tabular}{|l|} 
Algier \\
\end{tabular} & Aleksandria (6) & Afryka (1) & Bałkany (2) & Betania & Eden Nowy \\
\hline Anglia & Alwernia (1) & Azja (1) & Banat & Betlejem (8) & \\
\hline Argentyna (3) & Ateny (1) & Europa & Bawaria (1) & Betleem (1) & \\
\hline Australia & Bagdad (1) & & Bośnia (2) & Betleje (1) & \\
\hline Brazylia (4) & Belgrad (1) & & Galia (1) & Cedron (1) & \\
\hline Brezelia & Berlin (1) & & Galia Dolna (1) & Emaus (1) & \\
\hline Bułgaria (1) & Berlinek (1) & & Galia Górna (1) & Galilejka (1) & \\
\hline Chiny (2) & Budapeszt & & Galicja (5) & Galilea & \\
\hline Egipt (3) & Damaszek & & Himalaje & Golgota (5) & \\
\hline Florencja (4) & Drezno (1) & & Kamczatka (1) & Góra Oliwna & \\
\hline Francja (1) & Florencja (4) & & Kapkaz (8) & Jerozolima (4) & \\
\hline Hiszpania (1) & Grodno (5) & & Kapkazik (1) & Jeruzal (5) & \\
\hline Holandia (2) & Kaługa (3) & & Kapkazy (4) & Jeruzal-Kolonia (1) & \\
\hline India & Kijów (6) & & Kaukaz (3) & Jeruzal-Poduchowny (1) & \\
\hline Japonia (1) & Kłajpeda (3) & & Karpaty (9) & Jeruzale (1) & \\
\hline Kamerun & Kłajpedka (1) & & Luizjana & Jeruzalem (2) & \\
\hline Kanada (11) & Kołomyja (1) & & Madagaskar & Jerycho & \\
\hline Korea (37) & Kołomyjka (1) & & Manhattan & Jordan & \\
\hline Litwa (4) & Lizbona (1) & & Madera (9) & Józefata Dolina (1) & \\
\hline Luksemburg & Madryt & & Morawy (6) & Kalwaria (8) & \\
\hline Łotwa & Mec (3) & & Pacyfik & $\begin{array}{l}\text { Kalwaria-Lanckoro- } \\
\text { na (1) }\end{array}$ & \\
\hline Malta (3) & Mekka & & Sabaudia (1) & Kalwaria Pacławska (1) & \\
\hline Marokko & Nowy Jork (2) & & Sabaudy (1) & $\begin{array}{l}\text { Kalwaria Zebrzydow- } \\
\text { ska (1) }\end{array}$ & \\
\hline Meksyk (5) & Palmiry (1) & & Sahara (2) & Nowa Jerozolima & \\
\hline Panama & Parma (1) & & Syberia (13) & Palestyna (8) & \\
\hline Paragwaj (1) & Paryż (13) & & $\begin{array}{l}\text { Syberia Puc- } \\
\text { ka (1) }\end{array}$ & Synaj & \\
\hline Portugalia (1) & Pekin (2) & & Sybir (4) & Tabor (1) & \\
\hline Rosja (1) & Poczdam & & Sachalin (31) & & \\
\hline Serbia (1) & Praga (38) & & Tyrol (1) & & \\
\hline Szkocja (3) & Praha (1) & & Zatybrze (1) & & \\
\hline Szwajcaria (3) & Rzym (14) & & & & \\
\hline Szwecja (1) & Salamina (1) & & & & \\
\hline Ukraina (14) & Samary & & & & \\
\hline
\end{tabular}




\begin{tabular}{|l|l|c|c|c|c|}
\hline $\begin{array}{c}\text { Nazwy } \\
\text { państw }\end{array}$ & Nazwy miast & $\begin{array}{c}\text { Nazwy } \\
\text { kontynen- } \\
\text { tów }\end{array}$ & $\begin{array}{c}\text { Nazwy wysp, } \\
\text { krain geogra- } \\
\text { ficznych, gór }\end{array}$ & $\begin{array}{c}\text { Nazwy biblijnych } \\
\text { krain, rzek }\end{array}$ & $\begin{array}{c}\text { Nazwa mi- } \\
\text { tologicznej } \\
\text { krainy }\end{array}$ \\
\hline Watykan & Sedan & & & & \\
\hline Węgry (12) & Szanghaj & & & & \\
\hline Wietnam & Wagram (1) & & & & \\
\hline Włochy (4) & Wiedeń (3) & & & & \\
\hline & Wenecja (7) & & & & \\
\hline
\end{tabular}

* Liczby podane w nawiasie oznaczają wystąpienia danej nazwy w funkcji nazwy miejscowej, podane w „Wykazie urzędowych nazw miejscowości w Polsce” (WUNM). T. 1-3. Warszawa: Wydawnictwa Akcydensowe, 1980-1982. Brak przy nazwie informacji dotyczącej liczby wystąpień oznacza, że dana nazwa nie odnosi się do współcześnie istniejącego obiektu (miasta, wsi, kolonii, przysiółka, folwarku, części wsi, części miasta).

Większość późniejszych internacjonalnych nazw przeniesionych ma charakter pamiątkowy (por. Buczyński, 1997). Tworzy się je z uwagi na pochodzenie lub pewne związki twórców nazw lub ich bliskich z osadami, których nazwy ponawiano. Dla przykładu w drugiej połowie XVIII wieku, na obszarze dzisiejszej Ziemi Lubuskiej, powstaje wieś Malta. Określenie to nawiązuje do nazwy siedziby zakonu joannitów, którego przedstawiciele byli założycielami wspomnianej wsi ${ }^{7}$. Z kolejnego stulecia pochodzi osada Hiszpania z okolic Konina. Nazwano ją tak na cześć księżniczki hiszpańskiej, żony brata właściciela Wyszyny, któremu ten wydzielił nową osadę (SG III 73; NMPol III 482). Spora część nazw importowanych nawiązuje też do określeń miejscowości, w których odbywały się działania wojenne. Brali w nich udział Polacy lub o tych wydarzeniach było w kraju głośno. W XIX stuleciu powstaje kilka polskich wsi i kolonii nawiązujących do nazwy egipskiego miasta ${ }^{8}$ Aleksandria. Stały się one popularne po napoleońskiej kampanii egipskiej, w której uczestniczyli Polacy (NMPol I 11). Z kolei w nazwie Mec odnajdujemy echa zwycięstwa Prus nad Francją pod Metzem (Buczyński, 1997, s. 216).

Wśród dawnych toponimów, podobnie jak i tych współczesnych, rzadkością są przeniesienia nazw mitologicznych ${ }^{9}$. Pochodzą z końca XVIII wieku i wska-

7 Egzonim Malta pojawia się również na ziemi poznańskiej. W średniowieczu kawalerowie maltańscy zakładają szpital, następnie wznoszą młyn wodny, zwany Świętojańskim. W pobliżu lokuje się później karczmę i folwark o nazwie Malta (SG I 548). W XX i XXI wieku w wyniku ponawiania powstają: kino Malta, Jezioro Maltańskie (zwane potocznie Malta), galeria Malta, kolejka Maltanka, ulica Maltańska (Rutkiewicz-Hanczewska, 2008, s. 305, 393).

8 Niektóre z nazw, zwłaszcza określające miejscowości z obszaru byłego zaboru rosyjskiego, są homonimami. Utworzono je na cześć rosyjskiego rodu Aleksandrów Romanowów (NMPol I 11).

9 Z XIX wieku pochodzi też nazwa Eden Nowy. Nadał ją wsi Sieliszcze z powiatu kaniowskiego jej właściciel Adam Dorożyński. Członkowie jego rodziny nosili imiona biblijne: żona Ewa, synowie: Abel i Set (dziś obszar Białorusi) (SG XV/1, 468, zob. Bubak, 1966, s. 56). 
zują na specyficzne zainteresowania ich twórców. Wiążą się ze zmianą istniejących już nazw. Na skutek takiego procesu Helena Radziwiłłowa doprowadziła do przemianowania jednej ze wsi województwa łódzkiego, którą od 1780 r. nazywa się Arkadia (NMPol I 38).

$\mathrm{Z}$ początków XIX stulecia pochodzą również pierwsze osady motywowane nazwami egzotycznych krajów i miast w rodzaju Ameryka, Ateny, Parma, Paragwaj, Panama, Portugalia czy Palmira. Wiązać je należy z fascynacją egzotycznymi krainami, o których bądź tylko słyszano, bądź do nich podróżowano (por. nazwy Afryka, Bagdad, Chiny, Damaszek, Europa, India, Madera, Madagaskar, Pekin, Wiedeń). Zdaniem J. Bubaka (1966, s. 45) „szczególnie dużo takich egzotycznych nazw przenoszono na folwarki, dwory i karczmy". Ten rodzaj nominacji wiązać trzeba z masowym ruchem emigracyjnym oraz reemigracyjnym. Powracający z Ameryki czy innych krajów zakładali swoje osady, określając je nazwą kraju, z którego wracali. Inne nazwy stanowią z kolei świadectwo losu XIX-wiecznych zesłańców. Znakiem tych wydarzeń są propria w rodzaju: $\mathrm{Ka}$ luga, Kamczatka, Sybir, Syberia, Sachalin, Samara, Wiatka (Bubak, 1966, s. 47; Buczyński, 1997, s. 231, 243). Tak określane osady zakładano wówczas na wschodzie Polski, w rejonach dawnego zaboru rosyjskiego, a także na północy kraju (Pomorze Wschodnie).

Kolejne nominacje (z XX wieku) mają już charakter metaforyczny. Nazwy importowane stają się symbolami obszarów odległych od centrum, położonych z dala od wsi lub głównej części miasta (Ameryka, Sachalin, Syberia, Korea). Nie można wykluczyć również ich wyraźnie żartobliwego charakteru. Obiekt niepozorny, nieodpowiadający rangą czy wielkością swojemu nazewniczemu pierwowzorowi (Berlin, Kanada, Luksemburg, Paryż, Watykan, Wiedeń), musiał bawić ówczesnych swoją nazwą (zob. Bubak, 1966, s. 50).

XIX-wieczna moda na nazwy egzotyczne, za które uznawano określenia europejskich państw, miast i obiektów geograficznych, była bardzo silna i zaznaczyła się również $w$ innych grupach nazw niż miejscowe. Widać ją najlepiej wśród powstających w Europie zachodniej pod koniec XVIII stulecia nazw ogrodów zwanych etablissementami. Dla przykładu w Poznaniu upowszechniły się one w latach 30. następnego stulecia. Ich wyjątkowość polegała nie tylko na łączeniu funkcji konsumpcyjnej z rozrywkową oraz kulturotwórczą ${ }^{10}$, lecz także na bardzo oryginalnym ich określaniu nazwami odległych i egzotycznych krain (Nowa Ameryka, Eldorado, Nowa Syberia), państw (Columbia), wysp (Święta Helena) i miast (San Remo, Tivoli, Villa Tripolis), które do złudzenia przypo-

${ }^{10}$ Właściciele takich obiektów dostarczali swoim gościom wielu atrakcji. Na terenie ogrodu znajdowały się liczne altany, muszle koncertowe, podesty do tańca, sceny teatralne czy modne kręgielnie (Rutkiewicz-Hanczewska, 2009, s. 313-332). 
minają toponimy XX-wieczne, a nawet te z pierwszej połowy XXI stulecia. Na ten rodzaj nazywania wpłynęła bez wątpienia rozpowszechniona przez nurt romantyzmu potrzeba szerszego kontaktu z naturą, z egzotyką. Męcząca ówcześnie urbanizacja zmuszała mieszkańców do uciekania z nowoczesnego i zarazem dusznego miasta. To samo możemy powiedzieć i o dążeniach mieszkańców współczesnych miast, których tęsknoty wyrażają się w zbliżonym nazewnictwie, podkreślającym europejskość osad oraz zdrowy styl życia.

Przeniesienia z XX wieku kontynuują wytyczony wcześniej nurt nazewniczy o charakterze metaforyczno-metonimicznym. Rozszerza się repertuar przenoszonych nazw o kolejne choronimy, nazwy miast oraz obiektów geograficznych. Powiększa się również rejestr motywacji przenoszenia (także w odniesieniu do wcześniej wykorzystywanych architekstów), a dokładnie zaobserwowanych między referentami podobieństw, pozwalających na zaangażowanie utrwalonej kulturowo nazwy do nowej roli. Podstawą porównania obiektów jest bardzo często odległe położenie danego obiektu względem centrum. Nieprzypadkowo w tej funkcji pojawiają się nazwy następujących państw i wysp: Sachalin, Ameryka, Azja, Azory. Źródłem przeniesienia jest także zbliżony, często atrakcyjny krajobraz nominowanych obszarów, górzysty, nadwodny, z piękną roślinnością: Kaukaz, Szwajcaria, Holandia, Wenecja. Nierzadko również stopień zamożności mieszkańców danego terytorium pozwala na ich nazewnicze powielenie. Wówczas motywacja ma charakter negatywny. Dla przykładu nazwami typu Abisynia, Korea, Pekin czy Syberia określa się fragmenty wsi lub dzielnice miast kojarzone $\mathrm{z}$ biedą, a także z przestępczością. Oczywiście wymienione nazwy wiążą się z nagłośnieniem wiedzy o obiekcie danej nazwy, często w związku z różnego typu działaniami wojennymi. Od czasów konfliktu kolonialnego między Włochami i Abisynią pojawiło się w Polsce wiele nazw afrykańskiego państwa (w samym Poznaniu było ich cztery). To ono właśnie w latach 19351936 skupiło uwagę mieszkańców Europy z powodu inwazji dokonanej przez Włochy pod władzą Mussoliniego (Padalak, 2008, s. 619). W zbliżonej funkcji powstają też nowe przeniesienia toponimów biblijnych, pozbawione religijnej, znanej z XVII w. motywacji. Przysiółki o nazwach Betlejem czy Palestyna również wskazują na odległe od centrum położenie nowej osady, a nawet podkreślają niezamożność ich mieszkańców, wręcz biedę i nędzę, w jakiej żyją.

Warto zaznaczyć, że część dawnych przeniesień ma charakter pośredni. Wiąże się bardziej z upowszechnieniem nazwy brzmiącej na podobieństwo znanych wcześniej nazw miejscowości (w wyniku procesu adideacji) niż z jej pierwotnym przeniesieniem w momencie lokowania danej osady. Przykładem tak utworzonej nazwy jest Paryż pod Żninem. Źródła z XV w. poświadczają ją w postaci Parzysz (de Parzys, de Parzisch) od nazwy osobowej Parzych (NMPol VIII 319) lub Parys (Bubak, 1965, s. 50-73). W XVIII w. notowana jest już w postaci 
Paryż zapewne pod wpływem skojarzenia z upowszechnioną już nazwą stolicy Francji. Prymarnie przeniesione nazwy Paryż znajdujemy dla przykładu w rejonie byłego powiatu ostródzkiego oraz w południowej Warmii (Biolik, 1992, s. 104; Pospiszylowa, 1987, s. 111).

Wtórne skojarzenie z nazwą Moskwa wywołuje również nazwa osady z początków XV wieku, którą pierwotnie określano nazwą Moskiew (NMPol VII 253). Inne onimy mają charakter homonimiczny. Dla przykładu nazwy Praga czy Ukraina mogą należeć do nazw importowanych, jak i pochodzić od apelatywów w rodzaju praga 'miejsce po wypalonym lesie' (por. prażyć, palić) czy ukraina w znaczeniu 'odległe tereny, wysunięty obszar ziemi' (zob. Bubak, 1966, s. 51).

\section{WSPÓŁCZESNE PRZENIESIONE NAZWY MIEJSCOWE}

Po spopularyzowane w ubiegłych wiekach nazwy internacjonalne sięga się również obecnie, a zwłaszcza w ostatniej dekadzie XX stulecia. To zjawisko wyjątkowo charakterystyczne i bardzo istotne $z$ kulturowego punktu widzenia, swoistych uniwersaliów językowych, tym bardziej że w zasadzie nie uległ całkowitej zmianie ich repertuar. Także funkcja pozostała w zasadzie ta sama, a referent zmienił się jedynie dlatego, że ewoluowały realia współczesnego osadnictwa.

Dzisiejszą nazwą miejscową jest nazwa osiedla, dzielnicy, bloku czy modnego apartamentowca, który okazuje się dla współczesnych deweloperów bardziej prestiżowy niż blok czy dom (Naruszewicz-Duchlińska, 2010, s. 1). To przynajmniej w założeniu wielopiętrowy budynek mieszkalny z luksusowymi mieszkaniami nazywanymi apartamentami (Dubisz, 2003, s. 305). Sami deweloperzy zaznaczają, że ich apartamenty są idealną ofertą „dla osób zmęczonych mieszkaniem w tzw. blokowiskach”, a oferowane przez nich „bezczynszowe mieszkania mają klimat domu jednorodzinnego" (https://mieszkania.trovit.pl/listing/ sroda-wielkopolska-fredry). Podobne osiedla domków jednorodzinnych, budowane w wielu miastach naszego kraju, mają w ich zamierzeniu „odgrywać rolę luksusowych suburbiów" (Roszak, 2014).

Odmienność tego typu osiedla i mieszkania polega również na samym ich mianowaniu podkreślającym charakter miejsca. Zdaniem A. Naruszewicz-Duchlińskiej (2010, s. 306) „nazwy budynków stają się znakiem rozpoznawczym na tyle silnym, że zastępują ich adresy, a nawet niejako anektują ich rolę, przenosząc do innej kategorii onimów nazwy ulic, przy których są położone. Nie zawsze używa się przy tym numerów, co może sugerować, że apartamentowiec jest zarówno znakiem rozpoznawczym danej ulicy, jak i jedynym budynkiem godnym na niej zauważenia", można dodać, jest rodzajem osady, która nie wymaga numerowania. Jej nazwa sama w sobie wyróżnia się swoistą strukturą. 
W istocie tworzone współcześnie nazwy zarówno osiedli mieszkaniowych, jak i apartamentowców nie należą do neutralnych. Realizują w całej pełni funkcję perswazyjną komunikatu, za pośrednictwem którego deweloperzy prześcigają się, by potencjalny klient został przez te nazwy przyciągnięty. Ich część ${ }^{11}$ do złudzenia przypomina tworzone w przeszłości nazwy miejscowe o charakterze przeniesionym (zob. tabelę 2). Wśród nich znajdujemy nazwy krain geograficznych (Mała Toskania we Wrocławiu i w Środzie Wielkopolskiej), gór (Mont Blanc w Warszawie), jezior (Balaton w Bydgoszczy), rzek (Rubikon Residence w Warszawie), wulkanów (Etna w Kołobrzegu) czy nazwy miast (Osiedle Amsterdam w Warszawie), państw (Villa Monaco w Warszawie) i kontynentów (Willa Europa w Warszawie). Część z nich ma charakter przeniesień drugiego stopnia, które doskonale wpisują się w nurt nazw wtórnych. Niech za przykład takich form posłuży Balaton Apartamenty - nazwa bydgoskiej inwestycji zaplanowanej na 2020 rok, która nawiązuje do potocznej i zarazem przeniesionej nazwy pobliskiego akwenu (www.arkada-invest.pl/oferta/balaton).

O ile mogłoby się wydawać, że wymienione nazwy są wydumane, o tyle często tworzą one zamknięty system onimiczny. Dla przykładu na Osiedlu Europejskim w Krakowie kolejne apartamentowce noszą nazwy europejskich stolic: Amsterdam, Paryż, Bruksela, Londyn, Rzym, Reykjavik, Wiedeń itd. (www.krytykapolityczna.pl/kraj/miasto/roszak-mala-toskania-na-przedmiesciach), które przypominają takie dawne nazwy miejscowości i ich części motywowane nazwami państw, jak chociażby Hiszpania czy Ameryka. Ich zadanie z dzisiejszego punktu widzenia polega na przyciąganiu obietnicą sukcesu i europejskości. Ten zbiór dopełniają nazwy poszczególnych domów na osiedlu Eolian Park w Warszawie, nawiązujące do nazw poszczególnych Wysp Eolskich: Stromboli, Salina, Lipari, Vulcano, Panarea. Podobny system nazywania zaprojektowano na Osiedlu Wilno w Warszawie, gdzie oprócz podobieństwa architek-

11 W strukturze nazw apartamentowców znajdują się również nazwy ulic, dzielnic, imiona i nazwiska czy nazwy firm, a także „nacechowane melioratywnie apelatywy”. Oznacza to, że część z nich ma charakter opisowy, charakteryzuje położenie, wygląd budynku, jego konstrukcję, wysokość oraz kształt. Inne budują skojarzenia ze spokojem, z naturą i ekologią (Naruszewicz-Duchlińska, 2010, s. 306-309). Warto podkreślić, że część wspomnianych nazw to struktury obcojęzyczne w rodzaju Sea Towers w Gdyni, Capital Art Apartments w Warszawie, Angel Wings we Wrocławiu, La Lumiere w Warszawie, Playa Baltis w Międzyzdrojach, Casa Azul w Józefowie. Drugi model reprezentują deskrypcyjne nazwy polskojęzyczne, w dużej części nawiązujące do lokalizacji obiektu: Nowe Powiśle w Warszawie, Nowa Sienna w Poznaniu, Kamienica za Teatrem w Poznaniu, Apartamenty za Warta w Poznaniu. Badania prowadzone na zlecenie deweloperów pokazują, że pierwsza grupa nazw jest atrakcyjna dla młodszych użytkowników języka, z wykształceniem średnim oraz dla prywatnych przedsiębiorców. Z kolei nazwy związane z historią nowo zabudowywanej przestrzeni cenią użytkownicy starsi, z wyższym wykształceniem oraz przedstawiciele wolnych zawodów (www.bankier.pl/wiadomosc/Fajny-adres-czyli-jezykowe-i-lokalizacyjne-propozycje-deweloperow-2342481.html). 
Tabela 2. Rodzaje współczesnych intertekstów występujących najczęściej w funkcji nazw osiedli i apartamentowców

\begin{tabular}{|c|c|c|c|c|c|c|}
\hline $\begin{array}{l}\text { Nazwy } \\
\text { państw }\end{array}$ & $\begin{array}{c}\text { Nazwy } \\
\text { miast }\end{array}$ & $\begin{array}{l}\text { Nazwa } \\
\text { konty- } \\
\text { nentu }\end{array}$ & $\begin{array}{l}\text { Nazwy okręgów, } \\
\text { regionów geo- } \\
\text { graficznych }\end{array}$ & $\begin{array}{l}\text { Nazwy wysp, } \\
\text { jezior, rzek, } \\
\text { gór, wulkanów }\end{array}$ & $\begin{array}{l}\text { Nazwa bi- } \\
\text { blijnej kra- } \\
\text { iny }\end{array}$ & $\begin{array}{l}\text { Nazwa } \\
\text { mitolo- } \\
\text { gicznej } \\
\text { krainy }\end{array}$ \\
\hline Italia & Amsterdam & Europa & Lombardia & Etna & Eden & Arkadia \\
\hline Monaco & Ateny & & Toskania & Mont Blanc & Górski Eden & \\
\hline \multirow[t]{11}{*}[\mathrm{H}]{ Olandia } & Barcelona & & Sardynia & $\begin{array}{l}\text { Wyspy Eolskie } \\
\text { (Eolian) }\end{array}$ & & \\
\hline & Bruksela & & Sycylia & Stromboli & & \\
\hline & Kopenhaga & & Piemont & Salina & & \\
\hline & Lizbona & & Manhattan & Lipari & & \\
\hline & Londyn & & Skandynawia & Vulcano & & \\
\hline & Paryż & & & Panarea & & \\
\hline & Praga & & & Rubikon & & \\
\hline & Reykjavik & & & & & \\
\hline & Rzym & & & & & \\
\hline & Wiedeń & & & & & \\
\hline & Wilno & & & & & \\
\hline
\end{tabular}

tury, mającej w założeniu nawiązywać do miasta Wilna, również wewnętrzne uliczki, place i budynki uzyskały tzw. wileńskie nazwy, typu: ulica Montwittowska, plac Trynopolski (http://rynekpierwotny.pl/oferty/dom/developmentsa/wilno-warszawa-targowek-elsnerow-524/). Co istotne, bo przypominające XVII-wieczną tradycję zakładania kalwarii i ich upodabniania do pierwowzoru, również współcześnie twórcy przeniesionych nazw starają się, by nowe osiedla architektonicznie wpisywały się w nazewniczy krajobraz, i nie jest on jedynie włoski. Jak sama nazwa Parku Skandynawia w Warszawie wskazuje, znajdujące się na jego terenie budynki „mają białe ościeżnice, duże okna i nordyckie wzory kwiatowe w częściach wspólnych" (https://rynekpierwotny.pl/oferty/ skanska-residential-development-poland-sp-z-oo/park-skandynawia-warszawa-praga-poludnie-goclaw-9202/). Ten rodzaj przenoszenia nazw wiąże się ściśle ze współczesnymi tendencjami architektonicznymi, z dążeniem do koherencji w planowaniu przestrzeni, nazewnictwa i designu.

Zaznaczona wyżej spójność semantyczna, a także formalna dotyczy również relacji dawna nazwa dzielnicy - wspótczesna nazwa osiedla i apartamentowca. Oznacza to, że przeniesiona nazwa internacjonalna części miasta może stać się źródłem, motywem do utworzenia nazwy znajdującego się na jego terenie osiedla. Dla przykładu w warszawskiej historycznej już dzielnicy Włochy w latach 2012-2014 wybudowano osiedle o jakże znaczącej nazwie Zielona Italia, na terenie którego dziś znajdujemy apartamentowce określane nazwami włoskich regionów administracyjnych: Toskania, Sardynia, Sycylia, Lombardia i Piemont. 
To rodzaj onimicznego symbolu łączności między dawnymi i współczesnymi czasy, ujawniającego nie tylko charakterystyczną strategię marketingową deweloperów, ich świadome lub nieświadome dążenie do spójności krajobrazu nazewniczego, lecz także swoiste uniwersalia językowe. Nazwy internacjonalne, odegzonimiczne okazują się tak samo popularne i egzotyczne dla współczesnych, jak i dla naszych przodków. Nazwa warszawskiej dzielnicy Włochy ma bowiem proweniencję XVI-wieczną. Wtedy to upowszechniła się nowa nazwa dla osady Porzucewo, na pamiątkę nazwiska jej nowego właściciela Mikołaja Włocha (SG XIII 696). Zapewne nie oznacza to, że już w XVI stuleciu dla niektórych nazwa Włochy brzmiała bardziej egzotycznie niż Porzucewo. W tym wypadku motywacja była naturalna, spontaniczna, chociaż niepozbawiona wyraźnego motywu (por. nazwisko odetniczne).

Warto wspomnieć, że o ile z onomastycznego punktu widzenia wymienione nazwy kontynuują pewien model nazewniczy znany już z przeszłości, o tyle przeniesione nazwy w zderzeniu z nominowaną rzeczywistością mogą śmieszyć. Zdaniem współczesnych mieszkańców, a także dziennikarzy, działania deweloperów często kończą się tworzeniem „nazw pompatycznych, niezrozumiałych i śmiesznych" (Wojtczuk, 2008). Ta swoista nazewnicza oryginalność wynika często ze zderzenia wyszukanej nazwy, nawiązującej do odległych krain, miast i miejsc geograficznych świata, z niewyszukaną lokalizacją lub wyglądem samego osiedla ciasno zabudowanego apartamentowcami, pomiędzy którymi zaprojektowano niewiele zieleni i placów zabaw, do których wstęp jest ograniczony. O takim właśnie zderzeniu fantazji nazewniczej z rzeczywistością pisze autor artykułu pt. „Mała Toskania na przedmieściach”, jaki został opublikowany na łamach Krytyki Politycznej w 2014 r.:

Bliżej wjazdu na autostradę stoi baner reklamowy, który obwieszcza nazwę osiedla umieszczonego między polami i ruinami byłych PGR-ów — to „Mała Toskania”. Głębokie musi być rozczarowanie tych, którzy kupują dom w Toskanii, a muszą zamieszkać na obrzeżach Wrocławia. Rozdźwięk między reklamową opowieścią a rzeczywistością to nic wyjątkowego na rynku mieszkaniowym i nie ogranicza się on do inwestycji na Dolnym Śląsku. Osiedla deweloperskie pojawiają się jedne po drugich również w Krakowie, a przyszli mieszkańcy wierzą, że będą mieszkali w bezpiecznym, nowoczesnym i przyjaznym środowisku (Roszak, 2014).

Nie zawsze to zderzenie wywołuje uśmiech na twarzy użytkownika danej nazwy. Ona po prostu szokuje swoją niecodziennością. Nieprzystawalność nazwy do referenta w mniejszym stopniu zadziwia, gdy mowa o nazwach skansenów, miejsc specjalnie wydzielonych na pewnego rodzaju działalność, zwykle powiązaną z przepychem odrestaurowanych wnętrz i jakością oferowanych usług z zakresu odnowy biologicznej. Nie zmienia to faktu, że ich struktura także nawiązuje do dawnych toponimów motywowanych nazwami państw. Dla przykładu zrewitalizowany w 2010 roku majątek (folwark) we wsi Prusim, na tra- 
sie Poznań — Pniewy — Kwilcz, nazwano Olandia, czyli Kraina Wypoczynku $i$ Konferencji. Pięknie położone miejsce przysposobiono do pełnienia funkcji rekreacyjno-wypoczynkowo-gastronomicznych. Jego nazwa stanowi nawiązanie do dawnego osadnictwa olęderskiego (holenderskiego), jakie upowszechniło się w Wielkopolsce w XVII i XVIII w. i trwało aż do rozbiorów Polski, a najintensywniej rozwijało się w okolicy Nowego Tomyśla, sięgając aż do Pniew. Pierwsi osadnicy w istocie byli potomkami Holendrów z Prus Królewskich, których zadanie polegało na osuszaniu bagnistych, nizinnych obszarów i adaptowaniu ich do uprawy (Rutkiewicz, 2001, s. 155). Dzisiejsza Olandia to twór sztuczny, wieś Prusim nie była lokowana na prawie olęderskim. Stanowi jednak próbę restytuowania historii okolicznych osad, kontynuowania pamięci o ich pochodzeniu, a zarazem jest doskonałą, bo silnie nacechowaną perswazyjnie etykietą, wpisującą się w modne dziś, bo egzotyczne nazwy przeniesione nazywające osady, miejsca w szerokim tego słowa rozumieniu.

\section{WNIOSKI}

Dawne i współczesne nazwy internacjonalne przeniesione reprezentują dość powtarzalny rejestr onimiczny. Pomijając bogaty zbiór najstarszych przeniesionych nazw biblijnych, późniejsze przeniesienia powtarzają się także wśród tych współczesnych nominacji. W przeszłości (z początków XIX i XX wieku) były to głównie nazwy krajów, rzadziej nazwy miast czy krain i obiektów geograficznych. Dziś częściej spotykamy u podstaw charakteryzowanych toponimów nazwy europejskich miast i atrakcyjnych obiektów geograficznych (jezior, rzek, wysp, gór, wulkanów), rzadziej określenia państw. O ile w przeszłości nazwy biblijnych krain fascynowały i przyciągały, o tyle we współczesnym areale nazewniczym prawie ich nie ma, a jeśli są, to dotyczą utrwalonych kulturowo obrazów w rodzaju Eden.

Hiperteksty o biblijnej proweniencji pełniły funkcję sakralizowania przestrzeni, przenosiły uświęconą rzeczywistość za pośrednictwem określonego hipotekstu do nowych przestrzeni. Mówiąc językiem M. Eliadego (1999, s. 3435), dzięki przeniesieniom dokonywało się stworzenie nowego centrum świata, mikrokosmicznego obrazu uniwersum, poświęcenie małego kosmosu. Inne biblijne nominacje wskazywały na pochodzenie mieszkańców tak a nie inaczej nazwanych osad, miały charakter pamiątkowy, podobnie jak pozostałe historyczne nawiązania do nazw państw, regionów geograficznych czy miast. Można odnieść wrażenie, że także te współczesne przeniesienia odgrywają rolę imitowania upragnionych przestrzeni, w których fizycznie nie można zamieszkać, ale które chociaż z nazwy mogą je naśladować. Często w ramach koherencji kształtowania przestrzeni architektonicznie nawiązują do swoich pierwowzorów (por. Eolian Park, Osiedle Amsterdam, Park Skandynawia). 
Nazwy własne w sekundarnej funkcji, nazwy przeniesione nadal stanowią atrakcyjny materiał do nazywania nowych osad, osiedli, zwanych dziś modnie apartamentowcami, willami, atriami. Ich funkcja jest zbliżona do tych pierwszych nominacji. Dzięki pozytywnym konotacjom, jakie one ewokują u współczesnych, wiemy, że w cenie jest pogodne, zdrowe i spokojne życie we włoskim, wiejskim krajobrazie, najlepiej nad jeziorem, rzeką, wśród drzew czy w górach, a nawet u podnóża wulkanu. Istotnym jego elementem okazuje się również sukces i nowoczesność, które w symboliczny sposób przywołują nazwy europejskich stolic. Reasumując, zarówno dawniej, jak i dzisiaj twórcy nazw pokazują tęsknotę za stworzeniem nowego świata, już nie tego zamieszkanego przez Boga, w stricte religijnym wymiarze, lecz tego w wymiarze świeckim, gdzie dąży się do szczęścia, spokoju i radości.

Pamiętać przy tym należy, że część nazw (w funkcji określeń miejskich dzielnic czy części wsi), powoływanych w spontanicznym akcie kreacji, miała (i nadal może mieć) charakter negatywny, konotując ubóstwo i biedę. Tego typu asocjacje z pewnością się nie pojawią w świadomym akcie kreacji (w tworzeniu nazw dla apartamentowców).

Co istotne, podobnie jak w przeszłości, tak i teraz stosuje się podobne techniki powoływania nowych nazw. Część z nich nawiązuje do innych określeń za pośrednictwem związku bądź z nazwą danej osady, większej jednostki administracyjnej (miasta, dzielnicy), przyległej ulicy, bądź z nazwiskiem właściciela danej osady lub z nazwą koncernu budowlanego (Casa Verona, Concerto Verona, Tarasy Verona).

Współczesne nazwy jednych śmieszą, drugich zaskakują ${ }^{12}$. Warto jednak pamiętać, że tak jak w przeszłości, tak i teraz część z nich w zamierzeniu ich twórców świadomie do nich nawiązuje, część kontynuuje mniej świadomy model toponimiczny. To nazwy wiele mówiące o swoich twórcach. Pokazują, co dla

${ }^{12}$ Nazwy pierwotnie określające piękne krajobrazy w funkcji opisywania mało atrakcyjnych obszarów mogą zaskakiwać, lecz takie dysonanse widzimy także w nazewnictwie innych obiektów niż osiedla i apartamenty. $\mathrm{Z}$ podobnym zjawiskiem mamy do czynienia $\mathrm{w}$ grupie współczesnych plateonimów, których twórcy, zrywając z przytłaczającą oficjalnością tak popularnych do niedawna nazw pamiątkowych, coraz śmielej sięgają po struktury o charakterze sielsko-przyrodniczym, a także - nieobecnym we wcześniejszej urbanonimii - literacko-bajkowym. Pierwsze reprezentują określenia w rodzaju ulic Bzowa, Bławatkowa, Lipowa, Spokojna, Spacerowa, Czterech Wiatrów, Babie Lato czy Jelenich Rogów, Zajączków, Czyżyka, Sowy, Kukutek. Drugi, nowszy typ literacko-bajkowy jeszcze wyraźniej zrywa z monumentalnością dawnych nazw. Tworzą go struktury upamiętniające bohaterów różnych bajek, literackich, filmowych zarówno rodzimych, jak i obcych: Guliwera, Kopciuszka, Królewny Śnieżki, Leśnych Skrzatów, Lisa Witalisa, Pana Kleksa, Pana Twardowskiego, Smoka Wawelskiego, Ztotej Kaczki. I zapewne nie chodzi tu tylko o nowy materiał onimiczny, lecz także o sięganie po coś, co odmienne, lekkie, nieprzytłaczające, bardziej przyjazne, oswojone, a nawet z czasów beztroskiego dzieciństwa (Rutkiewicz-Hanczewska, 2016a, s. $341-355 ; 2016$ b, s. 151-159). 
człowieka jest atrakcyjne, wyrażają tęsknoty za tym, co piękne, dobre, kolorowe, nowe, egzotyczne. Pozwalają człowiekowi przenieść się za pośrednictwem tylko nazwy w inną przestrzeń, tę lepszą, czasem wymarzoną, długo oczekiwaną, radosną. Te z kolei uczucia i tęsknoty towarzyszące człowiekowi są niezmienne i wieczne. Już w epoce romantyzmu nasi przodkowie tęsknili za podobnymi krainami i cóż, niewiele się zmieniło. Ich tęsknoty wyrażane nazwami San Domingo, Święta Helena czy Nowa Ameryka, co prawda dla nazw etablissementów, czyli wyjątkowych ogrodów-restauracji, miejsc zabawy, także pokazują zafascynowanie egzotyką, spokojem, wypoczynkiem, bliskością z naturą, a to już o krok do dzisiejszej fascynacji ekologią i zdrowym stylem życia.

Przestrzeń onimiczna nas otaczająca coraz śmielej pokazuje współczesne tęsknoty. Powtarzają się trendy w stylu ubierania, jedzenia, życia, muszą się powtarzać i style nazywania. Instynkty ludzkie, marzenia i potrzeby zawsze będą zbliżone, mimo podlegającego ciągłym zmianom otoczenia.

\section{ŹRÓDŁA}

NMPol - Nazwy miejscowe Polski. Historia. Pochodzenie. Zmiany [Place Names of Poland. History. Origin. Changes]. T. I-. K. Rymut (red.) i inni. Kraków: IJP PAN, 1996-.

SG - F. Sulimierski, B. Chlebowski, W. Walewski. Słownik geograficzny Królestwa Polskiego i innych krajów słowiańskich [Geographical Dictionary of the Polish Kingdom and Other Slavic Countries] (wersja elektroniczna: dir.icm.edu.pl/Slownik_geograficzny).

WUNM - Wykaz urzędowych nazw miejscowości w Polsce [List of the Official Local Names in Poland]. T. 1-3. Warszawa: Wydawnictwa Akcydensowe, 1980-1982.

\section{LITERATURA}

Bilska, E. (1995). Przemiany kulturowych i religijnych funkcji kalwarii w Polsce [Cultural and Religious Functional Changes in Calvaries in Poland]. W: A. Jackowski (red.). Przestrzeń i sacrum. Geografia kultury religijnej w Polsce i jej przemiany w okresie od XVII do XX w. na przykładzie ośrodków kultu i migracji pielgrzymkowych [Space and Sacrum. Geography of Religious Culture in Poland and its Changes in the Period of the 17th to the 20th Century Based on Worship Centres and Pilgrimage Migration] (s. 201-220). Kraków: IGUJ.

Biolik, M. (1992). Toponimia byłego powiatu ostródzkiego [Toponymy of the Former Ostróda District]. Gdańsk: Wydawnictwo Gdańskie.

Borek, H. (1988). Nazwy relacyjne w toponimii [Referential Names in Toponymy]. W: K. Zierhoffer (red.). V Ogólnopolska Konferencja Onomastyczna [Fifth National Onomastic Conference] (s. 43-51). Poznań: Wydawnictwo UAM.

Breza, E. (1988). Nazwy lokali gastronomicznych w województwie gdańskim [Names of Gastronomical Places in the Gdańsk District]. Zeszyty Naukowe Wydziału Humanistycznego Uniwersytetu Gdańskiego. Prace Językoznawcze, 14, s. 115-123.

Bubak, J. (1965). Nazwy przeniesione w polskiej toponomastyce. Cz. I [Transferred Names in Polish Toponymy. Part I]. Onomastica, X, s. 50-73. 
Bubak, J. (1966). Nazwy przeniesione w polskiej toponomastyce. Cz. II [Transferred Names in Polish Toponymy. Part II]. Onomastica, XI, s. 43-61.

Buczyński, M. (1997). Pamiątkowe nazwy miejscowe w językach słowiańskich [Commemorative Local Names in Slavic Languages]. Lublin: UMCS.

Czerny, A. (2011). Teoria nazw geograficznych [Theory of Geographical Names]. Warszawa: Instytut Geografii i Przestrzennego Zagospodarowania PAN. Prace Geograficzne, 226.

Dubisz, S. (red.) (2003). Uniwersalny słownik języka polskiego [Universal Polish Language Dictionary]. T. 1. Warszawa: Wydawnictwo Naukowe PWN.

Eliade, M. (1999). Sacrum i profanum. O istocie religijności [The Sacred and the Profane. About the Nature of Religiousness]. Przeł. R. Reszke. Warszawa: Wydawnictwo KR.

Handke, K. (1989). Nazewnictwo miejskie (szkic teoretyczno-metodologiczny) [Urban Names (Theoretical and Methodological Studies)]. W: S. Urbańczyk (red.). Nazewnictwo miejskie [Urban Names] (s. 7-34). Warszawa-Poznań: Państwowe Wydawnictwo Naukowe.

Handke, K. (1998). Słownik nazewnictwa Warszawy [The Dictionary of Warsaw's Naming] Warszawa: Slawistyczny Ośrodek Wydawniczy.

Kopertowska, D. (1984). Nazwy miejscowe województwa kieleckiego [Local Names in the Kielce District]. Warszawa-Kraków: Państwowe Wydawnictwo Naukowe.

Kopertowska, D. (1993). Toponimy wtórne województwa radomskiego [Secondary Toponymy in the Radom District]. Slavia Occidentalis, 50, s. 35-67.

Naruszewicz-Duchlińska, A. (2010). Od Kamienicy Herbowej do Moscow Monster - o nazwach tzw. apartamentowców [From Noble Residence to Moscow Monster - on the Names of Apartments]. W: R. Łobodzińska (red.). Nazwy własne a społeczeństwo [Proper Names and Society]. T. II (s. 305-310). Łask: Wydawnictwo LEKSEM.

Myszka, A. (2016). Urbanonimia Rzeszowa. Językowo-kulturowy obraz miasta [Urbanonymy of Rzeszów. Linguistic-cultural Image of the City]. Rzeszów: Wydawnictwo Uniwersytetu Rzeszowskiego.

Ormeling, F. (2009). European Names in a 17th Century Atlas of the Dutch East India Company. In: W. Ahrens, S. Embleton, A. Lapierre (eds.). Names in Multi-Lingual, Multi-Cultural and Multi-Ethnic Contact. Proceedings of the 23rd International Congress of Onomastic Sciences (pp. 777-789). Toronto: York University.

Padalak, J. (2008). Słownik potocznego nazewnictwa poznańskiego [The Dictionary of Poznańs Colloquial Naming]. W: Zagórski (red.). Nazewnictwo geograficzne Poznania. Zbiór studiów [Toponymy of Poznań. A Collection of Studies] (s. 615-668). Poznań: Wydawnictwo Naukowe UAM.

Pawłowski, E. (1965). Nazwy miejscowości Sądecczyzny [Local Names in the Sącz District]. Kraków: Ossolineum.

Polański, K. (red.) (1995). Encyklopedia językoznawstwa ogólnego [The Encyclopaedia of General Linguistics]. Wrocław-Kraków: Zakład Narodowy im. Ossolińskich.

Pospiszylowa, A. (1984). Nazwy pojedynczych zabudowań mieszkalnych we wsi Istebnej [Names of Single Residential Buildings in Istebna]. Onomastica, XXIX, s. 91-113.

Pospiszylowa, A. (1987). Toponimia południowej Warmii: nazwy miejscowe [Toponymy of South Warmia: Place Names]. Olsztyn: Wydawnictwo Pojezierze.

Rospond, S. (1984). Słownik etymologiczny miast i gmin PRL [Etymological Dictionary of Cities and Communes of the Polish People's Republic]. Wrocław-Lódź: Ossolineum.

Rospond, S. (1985). Elementy biblijne w toponimii słowiańskiej [Biblical Elements in Slavic Toponymy]. Slavica Hierosolymitana, VII, s. 153-162.

Rutkiewicz, M. (2001). Sposoby tworzenia wielkopolskich nazw osad olęderskich [Methods of Dutch Settlement Name Forming in Wielkopolska]. W: A. Cieślikowa, B. Czopek-Kopciuch (red.). Toponimia i oronimia [Toponymy and Oronymy] (s. 155-168). Kraków: Wydawnictwo Naukowe DWN. 
Rutkiewicz-Hanczewska, M. (2007). Sakralny wymiar intertekstualizacji proprialnej [Sacral Dimension of Proprial Intertextualisation]. W: P. Bortkiewicz, S. Mikołajczak, M. Rybka (red.). Język religijny dawniej i dziś [Religious Language Formerly and Today] (s. 431-441). Poznań: Wyd. Poznańskie Studia Polonistyczne.

Rutkiewicz-Hanczewska, M. (2008). Nazwy terenowe [Local Names]. W: Z Zagórski (red.). Nazewnictwo geograficzne Poznania. Zbiór studiów [Toponymy of Poznań. A Collection of Studies] (s. 167-423). Poznań: Wydawnictwo Naukowe UAM.

Rutkiewicz-Hanczewska, M. (2009). Nazwy ogrodów, parków i ogródków działkowych Poznania — ewolucja gatunku [Names of Gardens, Parks, and Allotments in Poznań — Evolution of a Class]. Prace Filologiczne, LVI, s. 313-332.

Rutkiewicz-Hanczewska, M. (2013). Genologia onimiczna. Nazwa własna w płaszczyźnie motywacyjno-komunikatywnej [Onymic Genology. Proper Names on the Motivational and Communicational Level]. Poznań: Wydawnictwo Poznańskie.

Rutkiewicz-Hanczewska, M. (2016a). Literatura i literackość w nazewniczym krajobrazie Poznania [Literature and Literary Character in the Onomastic Landscape of Poznań]. W: J. Borowczyk, L. Marzec, Z. Kopeć (red.). Poznań pisarek i pisarzy. Materiały z sesji naukowej zorganizowanej z okazji Jubileuszu 45-lecia Instytutu Filologii Polskiej UAM w Poznaniu [The Poznań of Women and Men of Letters] (s. 341-355). Poznań: Wydawnictwo Naukowe UAM.

Rutkiewicz-Hanczewska, M. (2016b). Literatura na usługach miejskiej ikonosfery [Literature as a Servant of the Urban Iconosphere]. W: M. Biolik, W. Szulowska, E. Wolnicz-Pawłowska, W. Włoskowicz, A. Naruszewicz-Duchlińska (red.). Slavica. Onomastica. Regionalia. Prace dedykowane Panu Profesorowi Jerzemu Dumie [Works Dedicated to Professor Jerzy Duma] (s. 151-159). Olsztyn: Wydawnictwo Uniwersytetu Warmińsko-Mazurskiego.

Šrámek, R. (2010). K problematyce typologie názvů (českych) měst [About the Typology of Czech Names of Cities]. W: I. Sarnowska-Giefing, M. Graf (red.). Miasto w perspektywie onomastyki i historii [The City from the Perspective of Onomastics and History] (s. 39-49). Poznań: Wydawnictwo PTPN.

Treder, J. (1979). Nazwy ponowione wśród nazw przeniesionych [Reiterated Names among Transfered Names]. Onomastica, XXIV, s. 19-43.

Treder, J. (1980). Nazwy typu Betlejem, Brazylia, Warszawa na Kaszubach [Names such as Bethlehem, Brazil, Warsaw in Kaszuby District]. Jantarowe Szlaki, XXIII, s. 56-57.

Urbańczyk, S. (red.) (1991). Encyklopedia języka polskiego [Encyclopaedia of Polish Language]. Wrocław-Kraków: Zakład Narodowy im. Ossolińskich.

Wolnicz-Pawłowska, E. (2007). Nazwy geograficzne w kulturze narodu [Geographical Names in National Culture]. Prace Językoznawcze, IX, s. 147-156.

Zagórski, Z. (2008). Nazwy części miasta (dzielnic, osiedli, wsi, osad miejskich) [Names of Parts of the City of Poznań (Suburbs, Boroughs, Housing Estates, Settlements)]. W: Z. Zagórski (red.). Nazewnictwo geograficzne Poznania. Zbiór studiów [Toponymy of Poznań. A Collection of Studies] (s. 31-164). Poznań: Wydawnictwo Naukowe UAM.

Zierhofferowa, Z. (1988). Nazwy podziałowe. Podstawa wyodrębnienia, charakterystyka i klasyfikacja [Distributional Names. The Basis of Extracting, Description, and Classification]. W: K. Zierhoffer (red.). V Ogólnopolska Konferencja Onomastyczna [Fifth of National Onomastic Conference] (s. 289-295). Poznań: Wydawnictwo Naukowe UAM.

Zierhofferowa, Z. (1989). Nazwy typu Osiek Mały, Koźminek i inne derywowane od nazw miejscowych na przykładzie materiału $z$ dawnego województwa kaliskiego [Names such as Osiek Mały, Koźminek and other Derived Local Names by Means of the Example of Former Kalisz District Data]. Wrocław-Warszawa-Kraków-Gdańsk-Łódź: Zakład Narodowy im. Ossolińskich, Wydawnictwo Polskiej Akademii Nauk.

Zierhofferowie, K. i Z. (2007). Polska a Europa w świetle nazw geograficznych [Poland and Europe in Light of Geographical Names]. Poznań: Wyd. Poznańskie Studia Polonistyczne. 


\section{NETOGRAFIA}

Roszak, M. (2014). Mała Toskania na przedmieściach, tekst z 18 sierpnia 2014 r. [Little Tuscany in the Suburbs]. www.krytykapolityczna.pl/kraj/miasto/roszak-mala-toskania-na-przedmiesciach (dostęp: 11 II 2018).

Wojtczuk, M. (2008). W oparach absurdu czyli mieszkać na Wyspach Luksusu, tekst z 7 stycznia 2008 r. [In the Realm of Absurdity — Living on Luxurious Islands]. www.bryla.pl/bryla/1,85300,4814763.html (dostęp: 11 II 2018).

https://mieszkania.trovit.pl/listing/sroda-wielkopolska-fredry (dostęp: 31 I 2018).

Fajny adres, czyli językowe i lokalizacyjne propozycje deweloperów [Cool Address — Language and Location Offers from the Developers] (2011). www.bankier.pl/wiadomosc/Fajny-adres-czyli-jezykowe-i-lokalizacyjne-propozycje-deweloperow-2342481.html (dostęp: 18 II 2018).

http:// www.arkada-invest.pl/oferta/arkadia-3 (dostęp: 21 II 2018).

http://rynekpierwotny.pl/oferty/dom/development-sa/wilno-warszawa-targowek-elsnerow-524/ (dostęp: 21 II 2018).

https://rynekpierwotny.pl/s/nowe-mieszkania-warszawa/?page=4 (dostęp: 21 II 2018).

\section{SUMMARY}

THE RETURN OF NAMES IN THE CONTEXT OF LANGUAGE UNIVERSALS: ANCIENT AND CONTEMPORARY LOCAL NAMES WITH AN INTERNATIONAL CHARACTER

The article concerns the history and unique nature of local names derived from exonyms, such as Alexandria, Spain and Lisbon. It describes both past and contemporary onyms, i.e. the names of housing estates, such as Little Tuscany, and apartment buildings, such as Rome, London and Mont Blanc, which are the continuations of the toponymic model launched in the past. The author embeds this model of names in a broader cultural context by referring to language universals. In addition to the rich collection of the oldest biblical names that have been transferred to present names, transfers of old names can be observed among contemporary names. In the past (in the early nineteenth and twentieth centuries), these were mainly the names of countries and, less frequently, those of cities, lands and geographic objects. Today, toponyms are usually based on the names of European cities, attractive geographic objects (lakes, rivers, islands, mountains, volcanoes) and, more rarely, states. While the names of biblical lands were fascinating and attractive in the past, they are almost absent in contemporary names, and if they are present, they concern culturally fixed images such as that of Eden. Both formerly and today, the creators of this kind of names show a longing for the creation of a new world which is no longer inhabited by God in a strictly religious dimension, but a secular one where happiness, peace and joy are sought. In both characterised spaces, the names transferred serve commemorative functions and also imitate coveted spaces which cannot be physically inhabited but can at least be imitated by their names. Formerly, they were real imago mundi representing sacred places (e.g. names such as Calvary). Today, they are created as part of the contemporary architectural tendency for coherence in planning space, names and design.

Keywords: intertextual names, transonymization, exonyms, place names, names of apartments 